Copyright (C) 2021 by Cherkas Global University

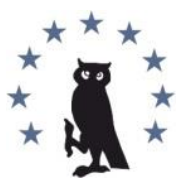

Published in the USA

Russkaya Starina

Has been issued since 2010.

E-ISSN: 2409-2118

2021. 12(2): 129-140

DOI: $10.13187 /$ rs.2021.2.129

https://rs.cherkasgu.press

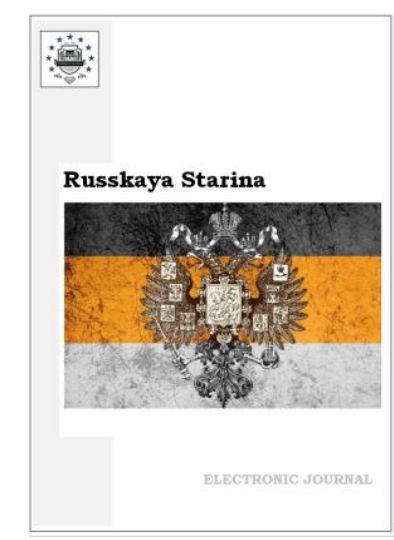

\title{
Reconstruction of the Forestry Fleet on Izhevsk and Votkinsk Ponds in the 1930-1950s
}

Nicholas W. Mitiukov a , b c , d,*

a Cherkas Global University, Washington, USA

b Udmurt Federal Research Center of the Ural Branch of the Russian Academy of Sciences,

Russian Federation

c Kalashnikov's Izhevsk State Technical University, Russian Federation

${ }^{\mathrm{d}}$ Moscow Institute of Psychoanalysis, Russian Federation

\begin{abstract}
The composition of the Udmurtia forestry fleets and ship biographies were reconstructed according to the annual technical and statistical reports of the Udmurtia's forestry. The "26-vod" form of statistical reports of forest-enterprise was of great importance in the post-war years the. However, until 1946 the completion of this or a similar form was usually ignored. In this connection, only the information on the vessels directly participating in the rafting can be reconstructed more or less reliably. But a comprehensive analysis of the reports makes it possible to identify auxiliary fleet vessels with a high probability.

In the second half of the 1920 forest divisions were separated from the Izhevsk and Votkinsk factories into separate enterprises, with the transfer of the former factory fleet to them. It is shown that until the 1940 s a process of enlargement of these enterprises is underway to provide fastgrowing enterprises of Izhevsk and Votkinsk with timber and timber products. But at the same time, the fleets are mainly equipped with former factory ships of pre-revolutionary construction: the Votkinsk's mechanical forest-station with the steamers "Azin", "Oktyabr" and the former barge of the Votkinsk's factory, the Selychka's timber station with the former steamer "Krasny Splavshchik" of the Izhevsk's factories. In the early 1940 s fleet renewal began, but it was interrupted by the outbreak of the Great Patriotic war, however, the Votkinsk mechanic foreststation received the "Pyatiletka" gas-generator boat, which was used during the war. In the postwar period, along with river transport throughout the country, technical re-equipment of the fleets of the forestry of Udmurtia began. New vessels with gas engines enter the enterprises, which are less labor-consuming to maintain compared to steam engines (the "Kirovets" boat of the "Izhles" trust, the half-glider of the Dulesovo's farm, the gas boat of the Votkinsk timber industry enterprise, etc.). Instead of the steamer "Krasny Splavshchik", handed over to the Izhevsk Production Office and the non-self-propelled barge of the Votkinsk timber industry enterprise, handed over to the "Mariles" trust, self-propelled barges arrive.

However, the development of the transport network, primarily the automobile and railway, as well as the power supply network, has led to the fact that since the 1950 os the need for firewood, as the main energy source, has fallen significantly. As a result, there was a serious reduction in the
\end{abstract}

\footnotetext{
${ }^{*}$ Corresponding author

E-mail addresses: nicoo2@mail.ru (N.W. Mitiukov)
} 
fleets of forestry enterprises in Udmurtia, and, as a result, a complete cessation of forest transportation through ponds.

Keywords: statistical report, technical report, Central Statistical Office, navigation, river transport, historical source, Izhevsk pond, Votkinsk pond, steamboat, fleet, forestry, timber industry, forest-station.

\section{1. Введение}

Водный транспорт представлял собой один из наиболее востребованных видов транспорта в СССР. Из-за огромных территорий и сравнительной неразвитости сети шоссейных и железных дорог долгое время он был единственным средством сообщения, связывавшим целые регионы с остальной страной. Из-за своей актуальности данная тема получила широкое освещение в отечественной историографии начиная с 20-х годов XX в., особенно в экономических, технологических и исторических аспектах. Однако история водного транспорта на региональном уровне рассмотрена совершенно недостаточно. Немногие работы по водному транспорту Удмуртии поднимали, зачастую лишь фрагментарно, историю судостроения на Воткинском заводе, в основном в экономикоорганизационных и социальных аспектах, а также историю водных перевозок по Каме крупнейшей водной артерии Урало-Поволжья. Что касается истории водного транспорта на замкнутых акваториях типа Ижевского и Воткинского прудов, то каких-то комплексных работ до сих пор не было, несмотря на то, что многие исследователи Ижевских и Воткинского заводов признавали высокую значимость перевозок по этим акваториям для обеспечения производства.

До середины XX в. основным энергоносителем Ижевских и Воткинского заводов оставались дрова, и от успешности подвоза леса в необходимом объеме зависело выполнение производственных программ. До середины 1920-х гг. лесными перевозками занимались соответствующие подразделения заводов, однако бурное развитие промышленности Удмуртии заставило организовать сеть специализированных лесозаготовительных и лесоперерабатывающих предприятий, которые и взяли на себя функции обеспечения лесом заводов Ижевска и Воткинска.

Задача данной работы состояла в том, чтобы определить состав и проследить эволюцию флотов лесных хозяйств Ижевского и Воткинского прудов, на которые легла функция обеспечения лесом имеющихся там заводов. Хронологические рамки определились датой организации в 1931 г. Воткинского мехлесопункта - первого лесного хозяйства Удмуртии, имевшего свой технический флот. Верхняя граница - 1957 г. - это дата ликвидации единого флота предприятия «Удмуртлес».

\section{2. Материалы и методы}

История эксплуатации судов, переданных в распоряжение хозяйствующих субъектов, неподотчетных центральным транспортным министерствам и ведомствам (Минречтрансу, Минречфлоту и т.д.), делает задачу реконструкции их карьеры нетривиальной. Если структуры типа пароходств постоянно издавали приказы и распоряжения, в которых фигурировали названия и регистровые номера имевшихся судов, то флоты лесных хозяйств жили по своим правилам и практически не упоминались в общих приказах по предприятию. Не вели они и традиционную для структур речтранса делопроизводственную документацию, например, ежегодные технико-эксплуатационные отчеты. В результате, по-видимому, эксплуатационная информация по флотам лесных хозяйств оказалась утраченной, в связи с чем выявление источников, в которых могут содержаться сведения о составе и состоянии флотов лесных хозяйств, дает возможность понять принципы их функционирования и в конечном итоге выявить значение этих небольших флотов при решении важных народнохозяйственных задач.

Условия ведения делопроизводственной документации на территории СССР предполагали заполнение традиционных годовых статистических отчетов, куда, кроме сводного баланса, входило множество приложений, сопоставляя которые за несколько лет подряд, можно выделить информацию, касающуюся флота. В послевоенные годы большое значение имела форма «26-вод», в которой подавались сведения о наличии или отсутствии у любого, даже самого маленького хозяйства собственных плавсредств. К сожалению, 
эта форма отсутствует в довоенных отчетах, eе роль частично выполняла форма 7 о техническом вооружении хозяйства. Однако по опыту ее заполнения не только для лесных хозяйств, но и вообще для большинства предприятий Удмуртии можно сделать вывод, что раздел водного транспорта обычно игнорировался. В связи с чем достоверно установить до 1946 г. можно лишь флот, непосредственно задействованный в лесосплаве. Сведения об остальных судах попадают в делопроизводственную документацию лишь эпизодически, например, разъездные катера могли фигурировать как потребители бензина по статье автотранспорта. Кроме того, успеха можно достичь лишь при комплексном анализе всего корпуса источников, например, в отчете об имеющихся в наличии паровых машинах может присутствовать судовая машина без прямого указания на это.

При работе с этим видом источников приходится иметь в виду два его главных недостатка: во-первых, в нем нередко есть ошибки, а во-вторых, там отсутствует поименное перечисление плавсредств. Первый недостаток обычно объясняется неаккуратностью составителя. Наиболее грубые ошибки обычно устранялись при личном контакте работника Статуправления и представителя предприятия, но множество менее существенных погрешностей так и могло оставаться в бланках. Что касается поименного списка судов, то без привлечения других источников обычно реконструировать его не представляется возможным. Это могут быть, например, акты инвентаризации имущества леспромхоза, техпромфинпланы или иные документы.

\section{3. Обсуждение и результаты}

Состав флотов лесных хозяйств по статотчетам в 1946-1956 гг. В 1946 г. при Совете Министров Удмуртской АССР было образовано Управление по технической эксплуатации малых рек. Оно сыграло большую роль в развитии водного транспорта в республике. Но самое важное: в Управление сходились все данные о водном транспорте, даже из неподотчетных Минречтрансу хозяйств. Это заставило леспромхозы более ответственно подходить к заполнению соответствующих статистических форм. Если до 1946 г. были нередки случаи, когда в итоговом отчете форма «26-вод» о наличии в хозяйстве водного транспорта сдавалась незаполненной, то с 1946 г. она стала заполняться регулярно. Поэтому представляется целесообразным использовать наиболее «проработанный» период в качестве опорной информации и начальной точки отсчета, после чего проследить эволюцию флотов по более ранним документам, которые, к сожалению, дают сведения о составе флотов крайне эклектично.

Имеющиеся данные статистических отчетов сведены в Таблице 1. Ранее нами была предложена методика расшифровки этих отчетов, с успехом примененная на материалах завода № 74 (Mitiukov et al., 2019) и флота Управления по транспортному освоению малых рек (Митюков, Баутина, 2020). Пользуясь ею, можно расшифровать эволюцию судового состава лесных хозяйств Ижевского и Воткинского прудов в период с 1946 по 1956 гг.

Таблица 1. Флоты хозяйств Минлеспрома Удмуртии по форме «26-вод» в отчетах ЦСУ (В - только Воткинский пруд, И - только Ижевский пруд)

\begin{tabular}{|c|c|c|c|c|c|c|c|}
\hline \multirow[t]{2}{*}{ Год } & \multicolumn{2}{|c|}{ грузопассажирский } & \multicolumn{2}{|c|}{ буксирный } & \multicolumn{2}{|c|}{ несамоходный } & \multirow{2}{*}{$\begin{array}{c}\text { Источник (все: } \\
\text { ЦГА УР. } \\
\text { Ф. Р-845. ОП. } 4)\end{array}$} \\
\hline & Шт. & мощн., л.с. & шт & мощн., л.с. & шт. & $\begin{array}{c}\text { грузоп., } \\
\text { т }\end{array}$ & \\
\hline $1946(И)$ & - & - & 1 & 115 & - & - & Д. 767. Л. 710б. \\
\hline $1946(\mathrm{~B})$ & - & - & 3 & 95 & - & - & Д. 799. Л. 37об. \\
\hline 1946 (B) & - & - & 4 & 125 & 1 & 400 & Д. 766. Л. 56об. \\
\hline 1947 (И) & - & - & 1 & 115 & - & - & Д. 951. Л. $420 б$. \\
\hline 1947 (B) & 2 & 90 & 2 & 106 & 1 & 250 & Д. 951. Л. 430б. \\
\hline 1948 (И) & 1 & - & 1 & - & - & - & Д. 1367. Л. 46об. \\
\hline 1949 & - & - & 5 & 209 & 2 & 412 & Д. 1738. Л. 58 \\
\hline 1949 & - & - & 6 & 358 & 2 & 415 & Д. 1568. Л. 11 \\
\hline 1950 & - & - & 6 & 358 & 2 & 415 & Д. 1941. Л. 16 \\
\hline 1951 & 1 & 73 & 5 & 281 & - & - & Д. 2311. Л. 17 \\
\hline
\end{tabular}




\begin{tabular}{|l|l|l|l|l|l|l|l|}
\hline 1953 & - & - & 5 & 246 & 2 & 40 & Д. 3123. Л. 17 \\
\hline 1954 & 1 & - & 7 & - & 2 & - & Д. 3584. Л. 46 \\
\hline 1955 & - & - & 10 & - & - & - & Д. 4016. Л. 410б. \\
\hline 1956 & 1 & 32 & 4 & 206 & - & - & Д. 4315. Л. 74 \\
\hline $1956($ И) & 1 & 32 & 1 & 110 & - & - & Д. 4315. Л. 81 \\
\hline $1956(В)$ & - & - & 3 & 96 & - & - & Д. 4315. Л. 82 \\
\hline
\end{tabular}

На 1946 г. Селыченский лесопункт (ЛП) имеет в своем составе один пароход с мощностью машины 115 л.с. с водоизмещением $41 \mathrm{~T}$, он числится в графе «буксирный» (ЦГА УР. Ф. Р-845. ОП. 4. Д. 767. Л. 710б.). В данном случае сомнений в его идентификации не возникает, это «Красный сплавщик», переданный в 1952 г. в состав Ижевской эксплуатационной конторы. Информация о нем дополняется техническим отчетом лесопункта, который имеет на балансе пароходную паровую машину в 35 л.с. Расхождение 35 и 115 л.с. смущать не должно - в одном случае указана эффективная мощность на гребном колесе, а во втором - индикаторная, мощность под поршнем. Эта паровая машина фигурирует в составе оборудования на начало года и конец года (ЦГА УР. Ф. Р-845. Оп. 4. Д. 767. Л. 169).

В 1946 г. в составе Воткинского мехлесопункта (МЛП) числятся два парохода и буксирный катер (ЦГА УР. Ф. Р-845. Оп. 4. Д. 799. Л. 37об.). Форма указывает всех их по статье «буксирные суда» с суммарной мощностью 95 л.с. (ЦГА УР. Ф. Р-845. ОП. 4. Д. 799. Л. 390б.). В другие годы у этого хозяйства числится баржа (табл. 1), но в 1946 г. ее почему-то нет. В последующих отчетах два парохода однозначно идентифицируются как «Азин» (48 л.с.) и «Октябрь» (28 л.с.). И тогда мощность буксирного катера с учетом округления составляет 20 л.с. В 1946 г. имеется еще один отчет по Минлеспрому УАССР, куда кроме Воткинского МЛП входит еще и трест «Ижлес» (4 судна в 125 л.с.). В результате довольно легко определяется, что во флоте последнего имеется катер с мощностью машины 30 л.с. И как дополнение к отчету Воткинского МЛП указана пропущенная там баржа в 400 т.

Отчет 1947 г. в Ижевске и Воткинске выделяет три лесных хозяйства, имеющих свой флот: Селыченский леспромхоз (ЛПХ) - «Красный сплавщик», 115 л.с. (ЦГА УР. Ф. Р-845. Оп. 4. Д. 951. Л. 420б.), и два хозяйства Минлеспрома УАССР, имеющие в сумме 2 буксирных парохода в 106 л.с. («Азин» и «Октябрь»), два буксирных катера в 90 л.с. и одну баржу в 250 т (ЦГА УР. Ф. Р-845. ОП. 4. Д. 951. Л. 430б.). В форме имеется примечание, что один катер числится на балансе Дулесовского леспромхоза (на Каме), остальные - в Воткинском МЛП. Как видно, мощность пароходов странным образом округлена до 106 л.с. вместо 76 л.с. Разница в 30 л.с. как раз составляет мощность судна, имевшегося в распоряжении «Ижлеса» на Ижевском пруду, что вряд ли случайно. Тем более что в отчете этого года судно нигде более не учтено. Так что, вероятно, в бланке допущена ошибка и следует читать три буксирных судна в 106 л.с., а не два.

Соответственно, если в Воткинском МЛП в прошлом году был катер в 20 л.с., то получается, что в Дулесово имеется судно в 70 л.с. $(90-20=70)$.

Некоторая неожиданность имеется в техническом отчете треста «Ижлес». В нем на начало и конец года имеется «Катер разъездной» (ЦГА УР. Ф. Р-845. Оп. 4. Д. 1082. Л. 490б.), который числится как приобретенный в отчетный период за 55 тыс. руб. (ЦГА УР. Ф. Р-845. ОП. 4. Д. 1082. Л. 6). Поскольку в статведомости за 1947 г. он не указан, очевидно, судно должно появиться на следующий год. К сожалению, проверить это невозможно, так как за 1948 г. статведомости отсутствуют.

То, что приобретенный катер треста «Ижлес» и имевшийся до того катер - разные суда, подтверждается отчетом 1948 г. На начало и конец года у треста в составе оборудования снова числится «пароход буксирный» и «катер разъездной» (ЦГА УР. Ф. Р-845. Оп. 4. Д. 1367. Л. 46об.). «Пароход буксирный» - это «Красный сплавщик», а «катер разъездной» - имевшийся ранее с мощностью 30 л.с.

В 1949 г. произошло объединение флотов нескольких лесных хозяйств во флот комбината «Удмуртлес». Поэтому на этот год на его балансе числится 5 самоходных судов общей мощностью 209 л.с. и два несамоходных суммарной грузоподъемностью 412 т (ЦГА УР. Ф. Р-845. ОП. 4. Д. 1738. Л. 58). Можно предположить, что в этой ведомости в числе 
несамоходных судов учтен «Красный сплавщик», поскольку его мощность составляет больше половины от указанных 209 л.с. и вряд ли он учитывался по этой статье. В качестве предположения, что грузоподъемность баржи Воткинского мехлесопункта в 1946-1947 гг. меняется от 400 до 250 т, это вполне вероятно. Например, баржа показана в 300 т, a «Красный сплавщик» - 112 т, с учетом обычной для отчетов путницы между лошадиными силами и тоннами (самоходные суда характеризовались мощностью, а несамоходные грузоподъемностью, и при переводе судна из самоходных в несамоходные и наоборот отчеты демонстрируют полное тождество этих параметров, лишь бы цифры совпадали).

С другой стороны, в 1947 г. в объединенном флоте Воткинского МЛП, Дулесовского леспромхоза и треста «Ижлес» имелось пять судов с суммарной мощностью 196 л.с. Получается, что в 1949 г. имеется увеличение мощности на 13 л.с., которые вполне могли появиться как погрешность округления.

Имеется еще один отчет за 1949 г., вероятно, из-за того, что в статуправлении указали на явную нестыковку в мощностях. К нему приложена пояснительная записка с калькуляцией, как были получены отчетные цифры (ЦГА УР. Ф. Р-845. Оп. 4. Д. 1568. Л. 11). А именно: «Красный сплавщик» (115 л.с.), «Азин» (48 л.с.), «Октябрь» (28 л.с.), два катера 92 л.с. (по ним имеется непонятное примечание: «на Каме Capan.» - на Каме в Сарапуле? Возможно, оно намекает на Дулесовский леспромхоз) - в сумме 283 л.с. К ним добавляется полученный в этом году новый катер, о котором написано также неразборчиво: «катер Кировск[ого] завода» или «катер Кировец [с] завода» в 75 л.с. Здесь стоит отметить, что в этом же году на балансе завода № 74 также появляется катер «Кировец» в 75 л.с. (ЦГА УР. Ф. Р-845. Оп. 4. Д. 1568. Л. 8), который в последующие годы параллельно с «удмуртлесовским» числится на балансе завода. Вряд ли это простое совпадение, возможно, речь идет о каких-то серийных катерах. Но, так или иначе, получается в сумме шесть судов в 358 л.с.

К статистической ведомости имеется примечание: «Увеличение за счет слияния с Минлесом. Ввиду технического состояния, регистр разрешил “Кр[асный] сплавщик" использовать как производственный». Таким образом, если шесть судов давали в сумме 358 л.с., то без «Красного сплавщика» получается пять судов с суммарной мощностью 243 л.с., что очень близко к отчетности «Удмуртлеса» за 1949 г., где числится пять катеров с суммарными 209 л.с. Указанное обстоятельство можно объяснить следующим соображением. В 1949 г. пароход «Красный сплавщик» производит ремонт своей машины, которую, возможно, временно убирают с баланса, но само судно продолжает значиться как пароход по некоторым формам отчета, по другим числясь баржей. Из-за этого в 1949 г. пять судов, а в 1950 г. - шесть (в том числе три парохода).

По-видимому, в ответ на указанное из Статуправления несоответствие цифр в форме 1949 г. снова приложена пояснительная записка. В ней среди прочего указывается: «В годовом отчете комбината "Удмуртлес" за 1949 г. по основной деятельности, основные показатели по речному флоту за 1949 год, согласно форме 26-вод показаны следующие: 1. Самоходного флота (транспортного) 5 единиц общ[ей] мощн[остью] 209 л.с. ... В текущей отчетности по форме 26-вод основные показатели речного флота за 1949 г. показаны: 1. Самоходного флота (производственного) 3 единицы общ[ей] мощн[остью] 186 л.с. ... Уточняя эти расхождения по телефону с Вашими сотрудниками тт. Кычановым и Пономаревой оказывается Удмуртлесокомбинат имеет 1. Самоходного флота (производств[енного]) 6 единиц общ. мощностью 358 л.с.» (ЦГА УР. Ф. Р-845. Оп. 4. Д. 1568. Л. 12).

Цифра 186 л.с. близка к суммарной мощности трех пароходов, если мощность «Красного сплавщика» округлить до 110 л.с. Здесь имеется в виду, что это буксирные суда, тогда остальные три получаются грузопассажирскими.

Имеется также «Акт приемки комбината “Удмуртлес" Главвостлеса Минлесбумпрома СССР» от 30 июня 1949 г., где в разделе «Техновооруженность» в составе Воткинского ЛПХ числится три парохода. Больше пароходов другие леспромхозы по этой ведомости не имеют (ЦГА УР. Ф. Р-1108. ОП. 3. Д. 1. Л. 91).

Наконец, в общем статотчете Речтранса УАССР за 1950 г. в графе «Удмуртлес» показаны шесть самоходных судов с суммарной мощностью 358 л.с. (ЦГА УР. Ф. Р-845. ОП. 4. Д. 1941. Л. 16), структура которых понятна по отчету 1949 г. Возможно, этот документ 
указывает на то, что предыдущий отчет был составлен ближе к концу 1949 г., чтобы как раз и обеспечить достоверными цифрами отчет за 1950 г.

Отчет 1951 г. показывает шесть судов с суммарной мощностью 354 л.с., в том числе одно грузопассажирское (73 л.с.) и пять буксирных (281 л.с.) (ЦГА УР. Ф. Р-845. Оп. 4. Д. 2311. Л. 17). На обороте формы имеется пояснительная записка: «3 буксирных парохода: 1 - 110 сил, 2 - 76 сил работали на буксировке древесины по пруду. 3 катера служебноразъездные и [для] вывода кошелей для буксировки». Пароход в 110 сил это «Красный сплавщик», два в 76 сил - это «Азин» и «Октябрь». В качестве грузопассажирского явно указан «Кировец» (73 л.с. вместо показанных ранее 75 л.с.). Соответственно на два разъездных катера приходится 281-110-76=95 л.с. (вместо 90 л.с.). Что интересно, кроме трех пароходов, в тресте имеются три «жидкотопливных» (т.е. бензиновых или дизельных) катера, все как на начало года, так и на его конец (ЦГА УР. Ф. Р-845. Оп. 4. Д. 2066. Л. 590б.). Выходит, что катера в Воткинске, Дулесово и «Кировец» - мотокатера или теплоходы.

Отчет 1953 г. показывает в «Удмуртлесе» пять судов, все буксирные, суммарной мощностью 246 л.с. (ЦГА УР. Ф. Р-845. ОП. 4. Д. 3123. Л. 17). По сравнению с предыдущими отчетами не хватает одного судна с мощностью 108 л.с. Учитывая возможность округления (два разъездных катера могут быть показаны с мощностью 90 л.с.), это явно «Красный сплавщик», переданный в Ижевскую эксплуатационную контору. По-видимому, составители отчета снова усомнились в корректности заполнения формы, и потому в ней карандашом приводятся другие варианты заполнения. Всего судов шесть в 418 л.с., в том числе четыре грузопассажирских в 323 л.с. и два буксирных в 95 л.с. Кроме того, на полях написано: «1 парох[од] - 172 [л.с.?]». В графе буксирных судов явно имеются в виду два катера на Каме, мощность которых в предыдущих отчетах указывалась в 90, 92 и даже 95 л.с. Тогда если «Азин» и «Октябрь» в сумме дают 76 л.с., а «Кировец» - 75 л.с., получается 323$76-75=172$ л.с.

Очевидно, проверяющий из Статуправления указал на явное несоответствие расчетных значений, не поняв о каком пароходе в 172 л.с. идет речь. В углу имеется примечание карандашом: «1 - пароход передан в управление малых рек» (имеется в виду «Красный сплавщик», переданный в Ижевскую эксплуатационную контору).

По отчету всего Управления малых рек за 1953 г. в тресте имеется на балансе две баржи в 40 т (ранее их не было) и пять ранее уже упоминавшихся буксирных судов в 246 л.с. (ЦГА УР. Ф. Р-845. Оп. 4. Д. 3123. Л. 17). Это «Азин» и «Октябрь» (76 л.с.), «Кировец» (75 л.с.) и два разъездных судна на Каме (95 л.с.).

В штатном расписании «Удмуртлеса» в расшифровке таблицы о наличии автотранспорта в Управлении комбината на 1949 г. указано, что кроме автомобилей там имеется катер, дающий в месяц 1000 км пробега при норме расхода 30 кг топлива на 10 км. Всего за год судно проходит 3000 км, в результате чего затраты на топливо составляют 2,7 тыс. руб. (ЦГА УР. Ф. Р-1108. Оп. 1. Д. 6а. Л. 46). В подобной же расшифровке к штатному расписанию на 1954 г. указано, что кроме автомобилей имеется катер, совершающий в месяц по 420 км пробега и имеющий нормы расхода горючего 30 л на 10 км пробега (ЦГА УР. Ф. Р-1108. Оп. 1. Д. 6. Л. 132). Судя по расходу топлива, в 1949 г. и 1954 г. в хозяйстве числился один и тот же катер. А поскольку он указан вместе с автомобилями, можно предположить, что его не указали в разделе водного транспорта и, скорее всего, это катер в 30 л.с., пропавший из отчетов в 1949 г. в объединенном «Удмуртлесе».

В 1954 г. в предприятии числились 2 парохода, 5 буксирных катеров, 1 разъездной катер и 2 самоходные баржи (ЦГА УР. Ф. Р-845. ОП. 4. Д. 3584. Л. 46). Пароходы получаются «Азин» и «Октябрь», самоходные баржи - те самые, что впервые упомянуты в 1953 г., разъездной катер - это может быть только тот, о котором говорилось в разделе автотранспорта. А вот относительно идентификации пяти буксирных катеров возникают вопросы. Два катера и «Кировец» имелись и ранее, получается, что флот пополнился сразу двумя судами. К сожалению, об их мощности ничего нельзя сказать из-за отсутствия в отчете формы «26-вод». Возможно, в буксирные катера ошибочно зачислили нигде более не упомянутую баржу Воткинского ЛПХ, но даже в этом случае появляется какое-то новое судно.

В 1955 г. в «Удмуртлесе» числится 2 парохода и 8 катеров (ЦГА УР. Ф. Р-845. ОП. 4. Д. 4016, Л. 410б.). Видно, что в число катеров зачислены как буксирные, так разъездные 
и самоходные баржи из предыдущего отчета. В этот год тресту «Марилес» по распоряжению Минлеспрома РСФСР от 7.05.1955 № Г-1379, подтвержденному телеграммой от 13.02.1956 г., переданы баржа (балансовая стоимость 56,2 тыс. руб.) и катер (стоимость 55,5 тыс. руб., износ 2,6 тыс. руб.) (ЦГА УР. Ф. Р-845. Оп. 4. Д. 4016. Л. 107).

1956 г. стал последним годом, когда у «Удмуртлеса» имеется свой флот. В итоговом статотчете предприятия за 1956 г. в оглавлении имеется запись о наличии формы «26-вод», но по факту она отсутствует (ЦГА УР. Ф. Р-845. ОП. 4. Д. 4345). В последующих отчетах 1957 г. (ЦГА УР. Ф. Р-845. Оп. 4. Д. 4837), 1958 г. (ЦГА УР. Ф. Р-845. Оп. 4. Д. 5241) и др. форма «26-вод» отсутствует даже в оглавлении.

К счастью, эта форма дублируется итоговым отчетом по Управлению малых рек (ЦГА УР. Ф. Р-845. Оп. 4. Д. 4315. Л. 74). В ней за комбинатом «Удмуртлес» числится пять судов суммарной мощностью 238 л.с., в том числе одно грузопассажирское в 32 л.с. (вероятно, новое, приобретение которого было вычислено в 1954 г.), и четыре буксирных в 206 л.с. В кратких пояснениях к отчету отмечено: «В число флота включены буксирные пароходы, катера и самоходные баржи». Таким образом, подтверждается приобретение в 1954 г. нового судна (32 л.с.), а также то, что проданная баржа Воткинского ЛПХ, скорее всего, ранее была ошибочно показана как самоходная. Безымянная разъездная лодка, бывшая еще в «Ижлесе», в форме снова не показана. Это доводит численность флота до двух пароходов и восьми катеров в предыдущий год.

Этим же отчетом объясняется факт отсутствия флота у «Удмуртлеса» в последующие годы. По-видимому, из треста выделили флоты двух леспромхозов (Чуровский и Воткинский). При разделе катер, находившийся в Дулесово, скорее всего, нашел нового хозяина или был приписан к Чуровскому ЛПХ.

Форма по Воткинскому ЛПХ показывает, что там имеются три буксирных судна в 96 л.с. В кратких пояснениях написано: «В число флота включены буксирные пароходы 48 и 28 л.с. и самоходная генераторная баржа 20 л.с.» (ЦГА УР. Ф. Р-845. Оп. 4. Д. 4315. Л. 82). Выходит, что упомянутые выше две баржи в 40 т на самом деле - самоходки по 20 л.с. (снова наблюдается полное тождество лошадиных сил и тонн вместимости для составителей отчета). В форме по Чуровскому леспромхозу (пос. Селычка, верховья Ижевского пруда) показано, что за ним числится одно грузопассажирское судно в 32 л.с. и одно буксирное в 110 л.с. без детализации, что это за суда (ЦГА УР. Ф. Р-845. Оп. 4. Д. 4315. Л. 81).

Буксирное судно в 110 л.с., вероятно, недавно приобретенное или появившееся из-за ошибки расчетах. Действительно, 110 л.с. +96 л.с. $=206$ л.с., как в объединенном отчете. Информация, что в Воткинске имеется генераторная баржа в 20 л.с., - четкое указание на то, что полученные в 1953 г. две баржи как раз и были самоходки $(2 \times 20=40)$ с обычной путницей между лошадиными силами мощности и тоннами грузоподъемности (одна в Воткинске, одна в Ижевске). Но тогда получается, что четыре судна в 206 л.с. у пока еще объединенного «Удмуртлеса» - это «Азин» и «Октябрь» (76 л.с.) и два камских катера в 90 л.с. Излишек в 40 л.с. как раз и составляют две самоходки, которые должны были идти в графе баржей, но в итоге никуда не попали. Таким образом, подтверждается, что в 1954 г. с баланса хозяйства списан именно «Кировец», переданный вместе с баржей «Марилесу».

Результаты расшифровки отчетов ЦСУ сведены в Таблице 2.

Таблица 2. Расшифровка статотчетов (Цифра - заявленная мощность или грузоподъемность, П - поставлен на баланс, $\mathrm{C}$ - снят с баланса, $\mathrm{X}$ - отсутствует в этом году)

\begin{tabular}{|l|l|l|l|l|l|l|l|l|l|l|}
\hline & 1946 & 1947 & 1949 & $1949^{2}$ & 1950 & 1951 & 1953 & 1954 & 1955 & 1956 \\
\hline «Азин» & 47 & 48 & 48 & 48 & 48 & 48 & 48 & Есть & Есть & 48 \\
\hline «Октябрь» & 28 & 28 & 28 & 28 & 28 & 28 & 28 & Есть & Есть & 28 \\
\hline Катер в Воткинске & 20 & 20 & 24 & 20 & 20 & 20 & 20 & Есть & Есть & 20 \\
\hline Катер у «Ижлеса» & 30 & 30 & 34 & $?$ & $?$ & $?$ & $?$ & Есть & Есть & $?$ \\
\hline $\begin{array}{l}\text { «расн. } \\
\text { сплавщик» }\end{array}$ & 115 & 115 & 0 & 115 & 115 & 110 & Х & Х & Х & Х \\
\hline Катер в Дулесово & - & 70 & 75 & 72 & 72 & 72 & 75 & Есть & Есть & 70 \\
\hline «Кировец» & - & $П$ & $?$ & 75 & 75 & 73 & 75 & Есть & С & Х \\
\hline
\end{tabular}




\begin{tabular}{|l|l|l|l|l|l|l|l|l|l|l|}
\hline Самоходка 1 & - & - & - & - & - & - & 20 & Есть & Есть & 20 \\
\hline Самоходка 2 & - & - & - & - & - & - & 20 & Есть & Есть & 20 \\
\hline $\begin{array}{l}\text { Грузопассажир- } \\
\text { ское }\end{array}$ & - & - & - & - & - & - & - & Есть & Есть & 32 \\
\hline & & & & & & & & & & \\
\hline СелычЛП & 115 & 115 & - & - & - & - & - & - & - & - \\
\hline ВотМЛП & 95 & - & - & - & - & - & - & - & - & - \\
\hline Ижлес + ВотМЛП & 125 & 196 & 209 & - & - & - & - & - & - & - \\
\hline Удмуртлес & - & - & - & 358 & 358 & 354 & 246 & 8 шт. & 8 шт. & 238 \\
\hline ВотЛПХ & - & - & - & - & - & - & - & - & - & 96 \\
\hline ЧурЛПХ & - & - & - & - & - & - & - & - & - & 52 \\
\hline & & & & & & & & & & \\
\hline Баржа 1 & 400 & 250 & 297 & 300 & 300 & $?$ & $?$ & Eсть $^{4}$ & С4 & Х \\
\hline & & & & & & & & & & \\
\hline Все баржи & & & $\mathbf{4 1 2}^{1}$ & $\mathbf{4 1 5}^{1}$ & $\mathbf{4 1 5}^{1}$ & - & $\mathbf{4 0}^{3}$ & $\mathbf{2 ~ ш т . ~}^{3}$ & $\mathbf{2}$ шт. ${ }^{3}$ & - \\
\hline
\end{tabular}

${ }^{1}$ Как баржа учтен «Красный сплавщик».

2 Уточненный отчет по объединенному тресту

з Учтены как несамоходные плавсредства самоходные баржи

4 Показан как буксирный

Флот Воткинского МЛП в 1930-1940 гг. Использование ежегодных технических отчетов лесных хозяйств не всегда помогает ответить на вопрос о составе их флотов. Если суда применялись для производственных целей, то они обязательно фигурировали как в техпромфинпланах, так и отчетах. Но суда вспомогательного назначения (разъездные, посыльные и т.п.), как правило, упомянуты лишь эпизодически, и реконструировать их биографию в полном объеме в рамках имеющейся источниковой базы вряд ли возможно. Тем не менее есть смысл проанализировать имеющуюся информацию о них.

В архивных фондах производственные отчеты и техпромфинпланы по Воткинскому МЛП появляются лишь в середине 1930-х гг., тем не менее есть и более ранняя информация о флоте этого хозяйства. В 1931 г. трест «Ураллес» принял решение об организации Воткинского МЛП. Маем этого года датировано письмо заведующего сплавом, в котором он описывает условия работы в новом лесопункте. В нем пароходы упоминаются во множественном числе (ЦГА УР. Ф. Р-522. Оп. 1. Д. 106. Л. 97), что указывает на наличие как минимум двух судов. За 1931 г. имеется также лист «По учету взаимных расчетов с трестом». Раздел $\mathrm{X}$ «По учету результатов по счету расходов будущих лет» говорит, что «Затраты по ремонту пароходов производятся в декабре и погашаются в навигацию 1932 г.» всего в размере 1548 руб. 85 коп. (ЦГА УР. Ф. Р-60о. ОП. 1. Д. 23. Л. 19). Множественное число также указывает на наличие к этой дате у хозяйства двух пароходов. А вот план 1932 г. уже прямо указывает на два парохода и баржу в составе хозяйства (ЦГА УР. Ф. Р-6оо. Оп. 1. Д. 27. Л. 120б.). Указанная документация позволяет утверждать, что уже с момента организации Воткинского МЛП он имел в своем составе пароходы «Азин» и «Октябрь» вместе с баржей.

Технический отчет Воткинского МЛП треста «Удмуртлес» за 1935 г. содержит следующую информацию о его флоте. Форма «Оборудование лесозаготовок и сплава» (ЦГА УР. Ф. Р-311. Оп. 1. Д. 453. Л. 55) указывает на наличие двух паровых судов с суммарной мощностью машин 76 л.с., имевшихся на балансе по состоянию на 1.01.1935 г. и 1.01.1936 г. В графе о наличии других моторных судов в ведомости стоит прочерк.

В отчете 1937 г. Воткинского МЛП заполненные формы снова изменились. Единственная форма, указывающая на наличие флота, - «Калькуляция мехтранспорта» (Форма 7) (ЦГА УР. Ф. Р-311. Оп. 1. Д. 535. Л. 278). Подобная форма для флота заполнялась впервые, тем не менее, поскольку формально пароходы имели двигатели на жидком топливе («Октябрь») и на дровах («Азин»), в таблице технико-производственных показателей их характеристики заполнены по отдельности.

Имеется также промфинплан Воткинского МЛП на 1938 г. В числе паровых судов там указаны в наличии два парохода суммарной мощностью 76 л.с., моторный катер в 30 л.с. 
и баржа тоннажем 350 т (ВГА. Ф. 154. Оп. 1. Д. 1. Л. 25). Это единственное упоминание о катере, а поскольку он более в отчетах не встречается, можно предположить, что это «Культура», построенная в 1938 г. Воткинским заводом для своих нужд.

Отчет за 1938 г. снова имеет новый набор форм, но есть форма, характеризующая транспорт, раздел V которой посвящен речному транспорту (ЦГА УР. Ф. Р-311. ОП. 1. Д. 561. Л. 69об.). Количество судов там не указано, но суммарная мощность 76 л.с. не оставляет сомнений, что это все те же «Азин» и «Октябрь». Несамоходный флот представлен неизвестным количеством барж суммарной грузоподъемностью 350 т. Это позволяет утверждать, что имеется в виду та же самая баржа.

Техпромфинплан 1940 г. в бланке «Техвооруженность» говорит о наличии «парохода колесного на твердом топливе 48 л.с.» («Азин»), «парохода винтового на жидком топливе 28 л.с.» («Октябрь») и «баржи сухогрузной, грузом 300 т.» (ВГА. Ф. 154. Оп. 1. Д. 3. Л. 14).

Техпромфинплан 1941 г. в форме 26 «План работы парового и моторного флота» указывает, что пароходы «Азин» и «Октябрь» предполагается эксплуатировать в течение 100 дней. Впервые появляется газогенераторный катер «Пятилетка» (6о л.с.) (ВГА. Ф. 154. Оп. 1. Д. 6. Л. 36).

Годовой отчет Воткинского МЛП за 1944 г. в форме по составу оборудования в разделе Б «Прочее оборудование» указывает два парохода, один буксирный катер и одно судно несамоходного флота. Все они были в наличии на 1 января 1944 г. и на 1 января 1945 г. (ЦГА УР. Ф. Р-845. ОП. 4. Д. 323. Л. 38об.). Годовой отчет по основной деятельности всего Наркомата лесной промышленности УАССР в форме по составу оборудования в разделе Б «Прочее оборудование» указал наличие двух пароходов и одной единицы несамоходного флота на начало и на конец года. Относительно буксирных катеров здесь сообщается, что на 1 января 1944 г. в народном комиссариате числись два катера, в том числе только один «установленный» (возможно, имеется в виду принятый на баланс, пароходы и баржа идут в разделе «неустановленных»), но на 1 января 1945 г. числится уже один катер, также повторяющийся в разделе «Установленные», оба парохода и баржи в этой графе также числятся как «установленные» (ЦГА УР. Ф. Р-845. Оп. 4. Д. 326. Л. 56об.).

Отчет Воткинского МЛП за 1945 г. на начало и на конец года в «Прочем оборудовании» указывает два парохода, буксирный катер и одну единицу несамоходного флота (ЦГА УР. Ф. Р-845. ОП. 4. Д. 565. Л. 410б.).

Поскольку начиная с 1941 г. и вплоть до появления ежегодных отчетов ЦСУ по форме «26-вод» в Воткинском МЛП упомянуты только данные четыре катера, можно предположить, что «Пятилетка» вошла в суммарную мощность 90 л.с., которые дают статистические отчеты на Каме. И тогда мощность катера из Дулесовского ЛПХ составляет 30 л.с. Это предположение подтверждается актом передачи имущества Дулесовского ЛПХ на баланс комбината Удмуртлес в 1949 г., где действительно фигурирует единственное судно хозяйства - катер № 35 с мотором СТЗ-30 (ЦГА УР. Ф. Р-1108., ОП. 1. Д. 81. Л. 37). А поскольку мощность этого мотора составляла 32 л.с., ее нередко округляли до 30 или до 35 л.с., в зависимости от предпочтений составителя документа.

Флот лесных хозяйств Ижевска в 1930-1940 гг. Относительно парохода Селыченского ЛП / ЛПХ сомнений не возникает. Это до 1938 г. пароход «Красная звезда» Ижевских заводов, после передачи Ижевской эксплуатационной конторе в 1952 г. ставший «Звездой». На период нахождения судна в лесных хозяйствах Ижевского пруда оно называлось «Красный сплавщик». Других пароходов в этом месте и в это время просто не было.

В отчете Ижлеспромкомбината за 1938 г. имеется справка к форме № 2 «О составе основных средств по годам приобретения» (за несколько последних лет) (ЦГА УР. Ф. Р-716. Оп. 2. Д. 5. Л. 66). В ней в разделе водного транспорта за 1935 г. есть запись «8», очевидно, имеется в виду стоимость в тыс. руб. на приобретение в этом году основных средств. Больше никаких приобретений в период с 1926 г. по 1936 г. в форме нет. Однако в детализации «Основные показатели по транспорту и связи» (форма 28) в части V «Водный транспорт» (ЦГА УР. Ф. Р-716. Оп. 2. Д. 5. Л. 139об.) указано, что в этом году на балансе числился один буксирный пароход с мощностью машины 44 л.с.

В разделе плановых показателей по речному транспорту на начало года имеется запись «не планировалось». Для советской документации это очень странно, поскольку процент выполнения плана всегда был важнее абсолютных показателей. Указанное обстоятельство 
можно объяснить лишь тем, что в этом году пароход приняли на баланс. Это также подтверждается отчетом Ижлеспромкомбината за 1937 г., где отсутствуют какие-либо упоминания, что в его составе имеются плавсредства (ЦГА УР. Ф. Р-716. Оп. 2. Д. 1). Таким образом, пароход «Красный сплавщик» приняли на баланс предприятия в 1938 г. К форме 28 имеется приложение в виде таблицы VI «Отчет о работе водного транспорта» (ЦГА УР. Ф. Р-716. Оп. 2. Д. 5. Л. 140). В ней прямо написано, что пароход не планировался, так как он поступил в Ижлепромкомбинат после 1 января 1938 г.

В 1938 г. в Ижлеспромкомбинате треста «Оборонлес» произошла смена управляющего. В приемном акте от 3 ноября 1938 г. в составе Селыченского ЛП по состоянию на 1 ноября этого года фигурирует один пароход (ЦГА УР. Ф. Р-716. Оп. 1. Д. 22. Л. 19). Других пароходов у треста нет.

В отчете Селыченского ЛП за 1940 г. указано, что в текущем году лесопункт затратил на ремонт парохода 4,2 тыс. руб., в том числе о,8 тыс. на вспомогательные материалы, при плане 5,0 тыс. (ЦГА УР. Ф. Р-716. Оп. 2. Д. 22. Л. 148).

В отчете за 1940 г. Ижлеспромкомбината в форме 26 впервые дается указание индикаторных сил парохода - 115 л.с. (ЦГА УР. Ф. Р-716. Оп. 2. Д. 24. Л. 69об.). Причем пароход числится как на 1 января 1940 г., так и на 1 января 1941 г.

Уже в отчете 1941 г. Селыченский ЛПХ указывает расходы по транспортировке грузов «своим пароходом» (ЦГА УР. Ф. Р-1089. Оп. 1. Д. 5. Л. 99 об.), хотя еще на начало года он планирует один «мотовоз» мощностью 10 л.с. (ЦГА УР. Ф. Р-1089. Оп. 1. Д. 2. Л. 180). Возможно, под цифрой 10 имеется в виду сумма приобретения (10 тыс. руб.), что вполне соответствует цене за моторную лодку. Велика вероятность, что это то же самое судно, что числится в статистических отчетах в период с 1946 по 1956 гг.

В отчете за 1942 г. один пароход числится у Селыченского ЛПХ на 1 января 1942 г. и 1 января 1943 г. (ЦГА УР. Ф. Р-1089. Оп. 1. Д. 18. Л. 13об.). Мощность его машин указана в 35 л.с. (ЦГА УР. Ф. Р-1089. ОП. 1. Д. 15. Л. 118).

В составе оборудования предприятия «Ижлес» на 1 января 1945 г. среди прочего числится одна паровая машина мощностью 35 л.с., установленная на пароходе, которая переходит на баланс 1 января 1946 г. (ЦГА УР. Ф. Р-845. Оп. 4. Д. 573. Л. 43). Причем капитальный ремонт парохода в этом году не проводился, а проводился он для неуказанного катера, имевшегося в конторе (ЦГА УР. Ф. Р-845. Оп. 4. Д. 573. Л. 66об.). Лист отчета по наличному флоту за этот год у предприятия отсутствует, хотя упоминание о нем имеется в описи отчета.

Эволюция судового состава. На основании делопроизводственной документации лесных хозяйств Ижевского и Воткинского прудов можно выделить справки по следующим судам.

За период с 1931 по 1957 гг. через все года проходят пароходы Воткинского МЛП / ЛПХ «Азин» и «Октябрь».

Пароход «Красный сплавщик» появляется в Селыченском ЛП Ижлеспромкомбината в 1938 г. Мощность его в этом году 44 л.с., в 1940 г. 115 л.с., а с 1941 по 1945 гг. - 35 л.с. С 1946 г. мощность постоянна и равна 115 л.с., далее до передачи в 1953 г. - 110 л.с.

Безымянная баржа Воткинского МЛП / ЛПХ числилась в хозяйстве с 1931 г. с переменной грузоподъемностью, списана в 1955 г. в связи с передачей «Марилесу» по балансовой стоимости 56,2 тыс. руб.

Генераторный буксирный катер «Пятилетка» (6о л.с.) появился в Воткинском МЛП в 1941 г. и находился в хозяйстве до середины 1950-х гг.

Безымянный катер «мотовоз» (как он назван в отчете) предприятия «Ижлес» (3о л.с.). Дата появления неизвестна, но, возможно, это случилось в 1941 г. и приобретен он за 10 тыс. руб. В 1945 г. прошел капитальный ремонт. Пропадал он в 1947 г., но, вероятно, просто из-за того, что использовался как разъездной. В 1949 г. упомянут среди автомобилей треста «Ижлес». В 1954-1955 гг., по-видимому, снова учитывается в общей статистике численности катеров «Удмуртлеса». Возможно, в 1956 г. передан другому хозяйству или списан.

Катер № 35 в Дулесово числился с момента приема в «Удмуртлес» до 1957 г.

Буксирно-пассажирский катер «Кировец» приобретен «Ижлесом» в 1948 г. за 55 тыс. руб., мощность 75 л.с. Списан в 1955 гг. в связи с передачей «Марилесу» по балансовой стоимости 55,5 тыс. руб. 
Две самоходные баржи (по 20 т., или л.с.) приняты на баланс «Удмуртлеса» в 1953 г. В 1956 г. переданы одна Воткинскому ЛПХ, вторая - Чуровскому ЛПХ.

Неизвестное грузопассажирское судно в 1954 г. появилось в «Удмуртлесе» (32 л.с.), в 1956 г. передано Чуровскому ЛПХ.

\section{4. Заключение}

Произведенная реконструкция судового состава лесных хозяйств Ижевского и Воткинского прудов показывает, что до 1950-х гг. обеспечение предприятий Ижевска и Воткинска дровами и лесоматериалами являлось одной из приоритетных задач водного транспорта Удмуртии. В 1950 г. происходит частичное техническое перевооружение судового состава: в послевоенный период во флот начали активно поступать суда с бензиновым двигателем. На место парохода «Красный сплавщик» и несамоходной баржи, переданных другим хозяйствам, приходят самоходные баржи.

Однако развитие транспортной сети, в первую очередь автомобильной и железнодорожной, а также сети электроснабжения привело к тому, что уже с 1950-х гг. необходимость в дровах как основном энергоносителе значительно упала. В результате произошло серьезное сокращение флотов лесных хозяйств Удмуртии.

\section{Литература}

ЦГА УР - Центральный государственный архив Удмуртской республики.

ВГА - Управление по делам архивов города Воткинска.

Митюков, Баутина, 2020 - Митюков Н.В., Баутина С.Л. Реконструкция судового состава по статистическим отчетам // Вопросы истории. 2020. № 2. С. 51-65.

Mitiukov et al., 2019 - Mitiukov N.W., Loshkarev A.N., Bautina S.L. Vessel's Composition of the Plant Number 74 ("Izhmash") in 1930-1950-ies // Russkaya Starina. 2019. 10(1): 26-31.

\section{References}

Mityukov, Bautina, 2020 - Mityukov, N.V., Bautina, S.L. (2020). Rekonstruktsiya sudovogo sostava po statisticheskim otchetam [Reconstruction of the shipboard according to statistical reports]. Voprosy istorii. 2: 51-65. [in Russian]

Mitiukov et al., 2019 - Mitiukov, N.W., Loshkarev, A.N., Bautina, S.L. (2019). Vessel's Composition of the Plant Number 74 ("Izhmash") in 1930-1950-ies. Russkaya Starina. 1(10): 26-31.

TsGA UR - Tsentral'nyi gosudarstvennyi arkhiv Udmurtskoi respubliki [Central State Archive of the Udmurt Republic].

VGA - Upravlenie po delam arkhivov goroda Votkinska [Office of the Archives of Votkinsk].

\section{Реконструкция состава флотов лесных хозяйств на Ижевском и Воткинском прудах в 1930-х-1950-х гг.}

\section{Николай Витальевич Митюков a, , c, d, *}

а Черкас глобальный университет, Вашингтон, США

ьУдмуртский федеральный исследовательский центр Уральского отделения Российской академии наук, Российская Федерация

с Ижевский государственный технический университет им. М.Т. Калашникова, Российская Федерация

${ }^{\mathrm{d}}$ Московский институт психоанализа, Российская Федерация

Аннотация. На основе ежегодных производственных и статистических отчетов лесных хозяйств Удмуртии производится реконструкция состава их флотов и судовых биографий. Если в послевоенные годы большое значение для этого имела форма «26-вод»

\footnotetext{
* Корреспондирующий автор

Адреса электронной почты: nicoо2@mail.ru (Н.В. Митюков)
} 
статистических отчетов, то до 1946 г. заполнение этой или аналогичной ей форм обычно игнорировалось. В связи с чем более-менее достоверно можно реконструировать лишь сведения о судах, непосредственно участвовавших в сплаве. Но комплексный анализ отчетов позволяет с высокой вероятностью определить и вспомогательно-разъездные суда флотов.

Во второй половине 1920-х гг. произошло выделение из состава Ижевских и Воткинского заводов лесных подразделений в отдельные хозяйства, с передачей им бывшего заводского флота. Показано, что до 1940-х гг. идет процесс укрупнения этих хозяйств для обеспечения лесом и лесоматериалами быстрорастущих предприятий Ижевска и Воткинска. Но при этом флоты в основном укомплектованы бывшими заводскими судами дореволюционной постройки: Воткинский мехлесопункт пароходами «Азин», «Октябрь» и бывшей баржей Воткинского завода, Селыченский лесопункт - бывшим пароходом Ижевских заводов «Красный сплавщик». В начале 1940-х гг. произошло обновление флотов, прерванное Великой Отечественной войной, тем не менее Воткинский мехлесопункт получил генераторный катер «Пятилетка», использовавшийся во время войны. В послевоенный период вместе с речным транспортом всей страны началось техническое перевооружение и лесных хозяйств Удмуртии. В хозяйства поступают новые суда с бензиновыми двигателями, менее трудоемкие при обслуживании по сравнению с паровыми машинами (катер «Кировец» треста «Ижлес», полуглиссер Дулесовского хозяйства, бензиновый катер Воткинского леспромхоза и т.д.). На место парохода «Красный сплавщик», переданного Ижевской эксплуатационной конторе, и несамоходной баржи Воткинского леспромхоза, переданной тресту «Марилес», приходят самоходные баржи.

Однако развитие транспортной сети, в первую очередь, автомобильной и железнодорожной, а также сети электроснабжения привело к тому, что уже с 1950-х гг. необходимость в дровах как основном энергоносителе отпала. В результате произошло серьезное сокращение флотов лесных хозяйств Удмуртии, а впоследствии и полное прекращение перевозок леса по прудам.

Ключевые слова: статистический отчет, технический отчет, ЦСУ, навигация, речной транспорт, исторический источник, Ижевский пруд, Воткинский пруд, пароход, флот, лесное хозяйство, леспромхоз, лесопункт. 